\title{
YHTEISKUNTATEORIA, EMANSIPAATIO JA VAPAUDEN JA VÄLTTÄMÄTTÖMYYDEN VALTAKUNNAT
}

\begin{abstract}
Gronow, Jukka: Yhteiskuntateoria ja emansipaatio. Tutkijaliiton julkaisuja no. 26. Helsinki 1984. 214 s.
\end{abstract}

Jukka Gro»owin Yhteiskuntateoria ja emansipaatio on kokoelma hänen pääosin aiemmin jo julkaistuja tekstejään. Tekstit käsittelevät Marxia, marxismia, Weberiä ja uudempaa kriittistä yhteiskuntateoriaa. Kuten Gronow itse esipuheessaan toteaa, ulottuu tekstien jänneväli "Marxin kapitalismikritiikin eksplikoinneista ja poliittisen taloustieteen kritiikin erikoisluonteen korostamisesta viimeisimpien kirjoitusten yrityksiin problematisoida Marxin keskeisiä teoreettisia lähtökohtia, mikä ehkä parhaiten tiivistyy toteamukseen Marxin kommunismiperspektiivin ratkaisevasta ongelmallisuudesta" (s. 1).

Teoreettisesti kantavin ja kestävin kokoelman artikkeleista lienee jo aiemminkin julkaistu $\mathbf{M a}$ terialistinen historiankäsitys ja klassinen poliittinen taloustiede, jossa H. J. Schanzin "kolmivaiheteorian" pohjalta systemaattisesti ja dokumentoiden käydään läpi Marxin suhdetta poliittiseen taloustieteeseen hänen eri kehityskausinaan. Ajankohtaisempaa ja siksi ehkä kiinnostavampaa materiaalia ovat kuitenkin Herbert Marcusen poliittisen teknologian kritiikin, Jürgen Habermasin kommunikativisen toiminnan teorian, André Gorzin työkeskustelun sekä kriittisen yhteiskuntatieteen luonteen ympärille ryhmittyvät artikkelit, jotka tosin myöskin kaikki ovat jo aiemmin julkaistuja. Erityisen hyvinä pidän Gronowin teesejä kriittistä yhteiskuntatiedettă varten.

Uusia artikkeleita kokoelmassa on kaksi: Poliittisen taloustieteen kritiikki vallankumouksen subjektia etsimässä, joka perustuu v. 1980 Kööpenhaminassa pidettyyn esitelmäăn, ja Rikkaus ja vapaa aika emansipaatiotavoitteina.
Edellinen artikkeli liittyy ensisijaisesti pyrkimykseen eksplikoida poliittisen taloustieteen kritiikin luonnetta, jälkimmäinen taas problematisoi Marxin kommunismiperspektiiviä. Jatkossa keskityn käsittelemään artikkelia Rikkaus ja vapaa aika emansipaatiotavoitteena ja jätän kokoelman muut sekä edellä mainitut että mainitsematta jääneet - lähinnä marxismia ja Max Weberiä käsittelevät - artikkelit käsittelyn ulkopuolelle.

Gronowin tarkoituksena on artikkelissa "tarkastella rikkautta Marxin emansipaatiotavoitteena ja keskustella eräistä moderneista tulkinnoista (Postone, Heller, Castoriadis, Schanz ja Lohmann) tässä yhteydessä. Kyse on siten aidon yhteiskunnallisen rikkauden käsitteestä ja siitä, miten kapitalismi tätä rikkautta antisipoi Marxin ekonomiakritiikissä esittämien käsitysten mukaan". (s. 192). Artikkelin "eräs keskeinen tulos" on, että "Marx ei työn käsitteestään johtuen kyennyt lainkaan problematisoimaan ja tarkastelemaan ei-esineellistyneitä tai ei-reifioituneita yhteiskunnallisia suhteita tai muodostumia" (s. 193; Gronow nojautuu tässä Theunissenin 1978 Marx-tulkintaan). "Voidaankin väittää, että Marxin kommunismi on kaiken yhteiskunnallisuuden tuolla puolen." (s. 193.) Otan seuraavassa esiin Gronowin monipolvisesta artikkelista kaksi teemaa: keskustelun "todellisen kommunismin" ongelmallisuudesta ja keskustelun vapauden ja välttämättömyyden valtakuntien suhteesta. Lopuksi keskustelen Gronowin ajattelutavasta poikkeavasta tavasta nähdä vapauden ja välttämättömyyden valtakuntien suhde.

\section{Todellinen kommunismi}

Tanskalainen Hans-Jørgen Schanz on tutkimuksissaan päätynyt siihen, että vaikka pääoma rajoittaakin tarpeiden kehitystä, eivät tarpeet muodosta pääoman kehityksen rajoitusta. Siksi tar- peita kriittisempi emansipaatiotavoite on vapaa aika, jonka kasvattamispyrkimykset aina suoraan törmäävät pääoman arvonlisäyksen rajoihin. Tämä ei kuitenkaan ole ainoa syy siihen, että tarve on ongelmallinen emansipaatiokäsitteenä. Marx nimittäin ajattelee - kuten Schanz on korostanut - kapitalismin luovan sekä tarpeiden universaaliuden ja rajattomuuden että niiden yksilöllisyyden. Tarpeiden universaalisuudesta ja rajattomuudesta seuraa niiden periaatteellinen tyydyttämättömyys ja niiden yksilöllisyydestä se, että kunkin yksilön on itse voitava määrittää tarpeensa. Tämä tekee Marxin kommunismin lippuun kirjoittaman tunnuksen "kultakin kykyjensä mukaan, kullekin tarpeidensa mukaan" ongelmalliseksi.

Marx esittää tunnuksen "kultakin kykyjensä mukaan, kullekin tarpeidensa mukaan" puhuessaan "todellisesta kommunismista" (die höhere Phase der kommunistischen Gesellschaft) Gothan ohjelman arvostelussa. Todellinen kommunismi on omilla jaloillaan seisova emansipoitunut yhteiskunta erotukseksi "kommunismin ensimmäisestä vaiheesta", kommunistisesta yhteiskunnasta "sellaisena, jollaisena se vasta muodostuu kapitalistisesta yhteiskunnasta ja jota siis joka suhteessa, niin taloudellisessa, siveellisessä kuin henkisessäkin suhteessa, rasittavat vielä syntymämerkkeinä sen vanhan yhteiskunnan viat, jonka kohdusta se on syntynyt"'(Marx 1979, 536; alleviiv. Marxin). Gronow referoi Marxin kantaa seuraavasti. "Kommunismin ensimmäistä vaihetta hallitsee Marxin mukaan vielä työaikaan perustuva tasaarvo: jokainen tuottaja saa yhteiskunnalta täsmälleen sen, mitä on sille antanutkin (työaika mittana, työraha maksuvälineenä) sen jälkeen kun yhteiskunnallisen työn tuotteesta on vähennetty tietyt kasautumis- ja sosiaalirahastot. Tällainen tasa-arvo on kui- 
tenkin Marxin käsityksen mukaan vielä epäaitoa; se on itse asiassa epätasa-arvoa. Se on nimittäin abstraktia eikä ota huomioon yksilöitä konkreettisina tarveolioina. - Yksilöitä verrataan samalla mitalla vain sillä ehdolla, ettă heitä tarkastellaan vain tietyltä kannalta, tässä tapauksessa työläisinä. Todellinen tasa-arvo saavutetaan vasta kommunismin korkeammassa vaiheessa, jolloin toteutuu aito verrannollisuus: kultakin kykyjensä mukaan, kullekin tarpeidensa mukaan. Vasta tällöin kukin yksilö on 'oman itsensä mitta'." (s. 202.) Tällainenkäsitys todellisesta kommunismista on kuitenkin ongelmallinen, koska se - kuten Gronow Cornelius Castoriadiksen (1978) Marx-kritiikkiä referoiden toteaa - "on mahdollinen vain, jos jokaisen yksilön katsotaan edustavan lajiolemustaan" (s.202). "Marx ylittää porvarillisen oikeuden ahtaat rajat säilyttäen kuitenkin sen universaalin muodon, joka itse asiassa muuttuu pseudouniversaalisuudeksi. - Ongelma ratkaistaan vain siten, että kaikki säb̆nnöt palautetaan yksilöiden toimintaan ja kaikki yhteiskunnalliset instituutiot, jotka välittävät yksityisen ja yleisen suhdetta, hävitetään." (s. 203.) Näin Marxin ajatus todellisesta kommunismista näyttää perustuvan "vanhan maailman" ajatukseen yksilöstä lajiolemuksensa edustajana ja sivuuttavan aidon yksilöllisyyden problematiikan (jota Marx toisaalla korosti). Koko "tarpeiden ja kykyjen rikkauteen perustuva emansipaatiokäsitys näyttää johtavan siihen, että kyvyt ja tarpeet oletetaan lajiolemuksen kyvyiksi ja tarpeiksi" (s. 204.)

\section{Vapaa aika aitona rikkautena}

Koska "tarvekonseptio ei - tarjoa kriteereitä - aidon rikkauden ja hyvän elämän määreiksi” on käännyttävä toisen mahdollisuuden puoleen. Se "perustuu vapaaseen aikaan ja siihen liittyviin ai- toon itsensätoteuttamiseen ja itse itsensä päämääränä olemiseen. Näistä on kyse vapauden valtakunnassa työn ja tarpeen tuolla puolen." (s. 204-5.) Gronowin mukaan Marxin erottelua vapauden ja välttämättömyyden valtakuntien välillä voidaan tulkita kahdella toisistaan poikkeavalla tavalla. Ensimmäistä tulkintaa hän kutsuu "aristoteliseksi" ja toista "kantilaiseksi".

Aristotelisessa tulkinnassa "toiminta vapauden valtakunnassa on - tulkittu toiminnaksi, jota tehdään sen itsensä vuoksi; työllä välttämättömyyden valtakunnassa taas on tulkittu olevan jokin toimintaan nähden ulkopuolinen telos, jonka vuoksi työtä tehdään. Jälkimmäinen liittyy aineelliseen tuotantoon ja aineenvaihduntaan luonnon kanssa, edellinen toiminta on sen sijaan vapaa kaikesta luonnonpakosta ja -välttämättömyydestä". (s. 205.) Tällaista tulkintaa edustaa mm. Hans-Jørgen Schanz (1981), joka Gronowin mukaan ei kuitenkaan ole loppuun saakka looginen, koska näkee tarpeilla olevan sekä jotain tekemistä vapauden valtakunnan kanssa (kaikinpuoliset tarpeet ovat rikkaan yksilöllisyyden ehto) että jotain tekemistä välttämättömyyden valtakunnan kanssa (tarpeilla on suhde työhön, johon aina liittyy luonnonpakon jäänne). Gronow tekee koko aristotelisen tulkinnan (ei vain Schanzin) kritiikin seuraavalla - mielestäni hieman hämäräksi jäävällä (vrt. jäljempänä seuraava keskusteluni aiheesta otsikon Vaihtoehtoinen tulkinta alla) - tavalla. "Kuten Lohman (1983) on huomauttanut ongelmana tällaisissa tulkinnoissa on se, että aina silloin, kun Marx puhuu itsensätoteuttamisesta emansipaatiopäämääränä, hän tarkoittaa lajiolemuksen itsensätoteuttamista. Tällöin työ välttämättömyyden valtakunnassa - johon toisin kuin Schanz väittää, myös tarpeen ja tarpeentyydytyksen työn rinnakkaiskäsitteinä voi laskea kuuluvan - on aina ulkoisen päämäärän määräämää ja siinä mielessä itse asiassa vieraantunutta toimintaa, kun taas ihmisen lajiolemus toteutuu aidosti ei-vieraantuneessa muodossa vain vapauden valtakunnan piirissä: lajiolemus ei ole keino jonkin ulkoisen päämäärän saavuttamiseksi, vaan sen toteuttaminen on päämäärä sinänsä. Lajiolemuksen itsensätoteuttaminen ei kuitenkaan ole mitään muuta kuin Stirnerin 'emansipaatiotavoite', jota Marx itse Saksalaisessa ideologiassa ironisoi. Marxin emansipaatiotavoite näyttää siten jäävän hänen itsensä ironisoiman 'vanhan maailman' vangiksi". (s. 206.)

Kantilainen tulkinta vapauden ja välttämättömyyden valtakunnista - joka Gronowilla tarkoittaa ensisijaisesti Georg Lohmannin (1983) ajattelua - on korostanut sitä, ettei Marxin erottelu työn ja toiminnan välillä välttämättä ole sama kuin Aristoteleella, koska myös esineiden tuottamiseen ja käyttämiseen liittyviä toimintoja voídaan tehdä niiden itsensä vuoksi. Lohmann vetääkin valtakuntien rajan toisin. "Välttämättömyyden valtakunnassa ihmisen suhdetta itseensä modifioi se, että hän jää riippuvaiseksi luonnonesineistä, jostakin ulkoisesta, häneen nähden vieraasta, ja voi siten olla suhteessa itseensä vain hallitsemalla jotain muuta. - Vapauden valtakunnassa, jossa ei esiinny suhdetta johonkin ulkoiseen, ihmisen on pelkästään suhteessa itsensä". (mt. sit. Gronow s. 207 mukaan.) Tällainen tulkinta uusintaa Gronowin mukaan Kantin dualismin "järjellä varustettujen olentojen aistimellisesta luonnosta, I jossa vallitsee luonnonkausaliteetti ja heteronomia, sekä yliaistimellisesta luonnosta, jota hallitsevat empiirisistä ehdoista riippumattomat moraaliset lait, joiden lähteenä on autonomia" (Kant, sit. Gronow s. 207 mukaan). Lohmann on itsekin huomauttanut 
tämän tulkinnan olevan ongelmallinen kahdessa suhteessa. "Ensinnäkin suhde luontoon määrittyy vain herruutena, luonnon rationaalisena hallintana. Materiaalisen rikkauden kriteerinä on vain yhä täydellistyvä luonnonherruus, johon ei lainkaan liity intersubjektiivisia sosiaalisia suhteita. Toiseksi toiminta vapauden valtakunnassa määrittyy vain negatiivisesti: se riippuu vain toimijan omasta vapaasta tahdosta. Lohmannin mukaan tällöin ei ole mahdollista esittää mitään sellaisia kollektiivisia arviointikriteereitä, joiden avulla voitaisiin arvioida sosiaalisten suhteiden oikeudenmukaisuutta tai moraalisia sääntöjä ja normeja. Aito rikkaus 'hyvänä elämänä' jää siten määrittelemättömäksi." (s. 208.) 'Hyvää elämää' voitaisiin toki pyrkiä määrittelemään Marxin tavoin yksilöiden vapaana assosiaationa, mutta kuten edellä "todellisesta kommunismista" keskusteltaessa on havaittu, tämä ajattelutapa "ratkaisee" yksilön ja yhteisön välitysongelman vain olettamalla yksilön välittömästi edustavan lajiolemusta. Tămä taas liittyy siihen että "kuten Theunissen (1978) on todennut, Marx ei voi lainkaan tarkastella ei-vieraantuneita yhteiskunnallisia suhteita; Marxin työn esineellistymiskäsityksestä johtuu, että kaikki yhteiskunnalliset objektivaatiot ovat välttämättä vieraantuneita. Jokainen vakavasti otettava suhde yksilön ja jonkin toisen välillä on jo osoitus vieraantuneisuudesta." (s. 209).

Mutta palatkaamme kantilaiseen tulkintaan. Ongelmallisuudestaan huolimatta sillä on sankarinsa: Jürgen Habermas. "Hän on pyrkinyt teoksessaan 'Theorie des kommunikativen Handelns' kehittämään sellaisia 'hyvän elämän' kriteereitä, jotka koskevat - näin voidaan tulkita - vapauden valtakuntaa (Habermasilla 'Lebensweltiä') ja joiden tarkastelun marxismi on laimin- lyönyt. Habermas tosin säilyttää Kantin ja Marxin dualismin mutta esittää vapauden valtakunnan organisaatioprinsiipiksi kommunikatiivisen toiminnan vapauden. Habermasin normien käypyyttä ja hyvyyttä koskevat säännöt ovat kaiken lisäksi kategorisen imperatiivin tavoin sekä siinä mielessä universaaleja, että ne koskevat kaikkia, että siinä mielessä pelkästään kunkin yksilön järjenkäyttöön perustuvia, että jokainen voi vaatia niiden perustelemista ja asettaa ne kyseenalaisiksi. Habermas on siten esittänyt sellaisen aidon vaihtoehdon mitä mieltä siitä muutoin ollaankin - vapauden valtakunnan organisaatioperiaatteeksi ja 'aidon rikkauden' kriteeriksi, joka ei palaudu ihmisen lajiolemuksen toteutumiseen - niin kuin Marxin omat luonnehdinnat kommunismista". (s. 209-210.) Lohmannin ongelma välttämättömyyden valtakunnan intersubjektiivisista suhteista ja luonnonhallinnan instrumentaalisuudesta ei tosin ratkea Habermasin systeemissä, mutta ainakin se - "mitä mieltä siitä muutoin ollaankin" - osoittaa mahdolliseksi käsitellä vapauden valtakunnan intersubjektiivisia suhteita samaistamatta yksilöä ja ihmislajia toisiinsa.

Artikkelinsa lopussa ei Gronow tahdo esittää omaa positiivista vaihtoehtoaan. Tulos on silti saavutettu. Nimittäin se, että "Marx ei näytä voivan ajatella sellaisia aitoja yhteiskuntasuhteita, jotka eivät olisi vieraantuneita, eikä yksilön itsensätoteuttamista muutoin kuin lajiolemuksen toteutumisena" (s. 210). "Samalla kun välttämättömyyden valtakunnan piiriin kuuluva työ, suhde luontoon, käsitetään ongelmattomasti herruussuhteeksi, jossa toteutuu ihmiskykyjen ja -tarpei.den rajaton kehitys, vapauden valtakunnan vapaa aika tyhjenee kaikista intersubjektiivisista suhteista tarpeiden ja intressien tuolla puolen olevaksi yksilön tahdon vapauden toteutumaksi." (s.210.)

\section{Vaihtoehtoinen tulkinta}

Gronowin mukaan aidon rikkauden ja hyvän elämän kriteerinä voivat toimia joko vapaa aika tai tarpeet. Kun "todelliseen kommunismiin" liittyvä tarvekonseptio osoittautuu ongelmalliseksi, Gronow pyrkii määrittämään aitoa rikkautta ja hyvää elämää pelkän vapauden ja välttämättömyyden valtakuntien välisen erottelun pohjalta. Tässä hän eroaa sekä Herbert Marcusesta, jonka mukaan emansipoituneen yhteiskunnan "kaksi perusominaisuutta olisivat elintärkeiden tarpeiden täysi tyydytys ja vapaa aika" (Marcuse 1969, 237) että HansJørgen Schanzista, jonka mukaan pätee, että "ilman kaikinpuolisia tarpeita ei rikasta yksilöllisyyttä, ilman toimintoja, joissa yksilö on itse itsensä päämäärä (vapauden valtakunnan määritelmä Schanzille - RH), ei ole mitään vapaata yksilöllisyyttä" (Schanz 1981, 298). Tolsin kuin Gronow, joka pyrkii näkemään aidon rikkauden pelkkänä vapauden valtakuntana, määrittävät sekä Marcuse että Schanz sitä yhteydessä vapauden ja välttämättömyyden valtakuntien suhteeseen. Tällöin myös tarpeet (jotka niitä tyydyttäviä käyttöarvoja tuottavan työn kautta ovat sidoksissa välttämättömyyden valtakuntaan) tulevat osaksi aidon rikkauden määrittelyä, vaikka ajatuksesta vapauden ja välttämättömyyden valtakunnista ei luovutakaan.

Luopuminen tarpeista aidon rikkauden yhtenä määreenä johtaa siihen, että Gronow vapauden ja välttämättömyyden valtakunnista keskustellessaan tekee molemmissa malleissa valtakuntien välisen rajanvedon toiminnan luonteen eikä sen y'hteiskunnallisen määrävtyneisyiden perusteella. Aristotelisessa mallissa välttämättömyyden valtakunnan työ toteuttaa ulkoista päämäärää (ja vetää näin käyttöarvo-orientoituneisuutensa nojalla jopa tarpeetkin välttämättömyyden val- 
takuntaan), kantilaisessa mallissa välttämättömyyden valtakuntaan kuuluu kaikki esineellinen toiminta. Tällainen tapa vetää valtakuntien välinen rajaviiva näyttäisi eroavan Marxin tavasta tehdä tämä erottelu. Marx nimittäin (kuten Tapani Leino on minulle huomauttanut) näkee vapaan ajan yhteiskunnallisesti välttämättömän työn suorittamiseen kuuluvan ajan rinnakkaiskäsitteenä: mikä on toista ei ole toista.

On siis pidettävä loogisesti toisistaan erossa vapaan ajan (freie Zeit tai disposable time) käsite, joka viittaa yhteiskunnallisesti välttämättömän työn suorittamiseen kuluvan ajan ulkopuolelle jäävään aikaan, ja ajatus aidosta itsetoteutuksesta. Vapaan ajan käsite viittaa kokonaisyhteiskunnallisen analyysin tasolle. Tämä näkyy siitä, että vapaa aika Marxin mukaan esiintyy kapitalismissa antagonistisessa muodossa mikä tarkoittaa sitä, että vain osa siitä on työläisen itsensä käytettävissä samalla kun pääoma jatkuvasti pyrkii muuttamaan tuotantovoimien kehityksen myötä syntyvää vapaata aikaa lisätyöajaksi (ks. Grundrisse 596; Schanz 1981, 297; Oetzel 1978, 186, alaviite). Kaikki vapaa aika ei siis kapitalismissa realisoidu työläisten vapaa-aikana eikä edes kaikki vapaa-aika luonnollisestikaan ole aitoa itsetoteutusta.

Jos edellä mainittu pääoman pyrkimys vapaan ajan anastamiseen (siis lisätyöajan riistoon) poistettaisiin pääomasuhteen kumoamisella, jäisi koko vapaa aika työläisten omaan käyttöön. Tämä vapaan ajan alue muodostaisi vapauden valtakunnan yhteiskunnallisesti välttämättömästä tuotannosta huolehtivan välttämättömyyden valtakunnan ulkopuolelle. Näin syntyisi siis kaksi yhteiskunnallista sfääriä. Kokonaisyhteiskunnallisella tasolla tarkastellen voitaisiin välttämättömyyden valtakunnalle antaa se määre, että se on - "aristotelisesti" puhuen - ulkoisen tarkoituk- sen, nimittäin tarvetyydytyksen (yhteiskunnallisesti välttämättömänä pidetty käyttöarvotuotanto), määräämää ja siinä (mutta vain siinä) mielessä poiesiksen aluetta. Kun Marx sanoo, että "vapauden valtakunta alkaa tosiasiassa vasta siellä, missä puutteen ja ulkopuolisen tarkoituksenmukaisuuden sanelema työnteko loppuu, siis asian luonteesta johtuen se on varsinaisen aineellisen tuotannon alueen tuolla puolen" (Marx, 1976, 807-808, kursiv. $\mathrm{RH}$, hän ymmärtääkseni viittaa juuri välttämättömyyden valtakunnan yhteiskunnalliseen määräytyneisyyteen (etenkin kun hän samassa kohdassa hieman jäljempänä puhuu tämän alueen historiallisesta laajenemisesta tarpeiden kehittymisen myötä ja sen supistumisesta tarpeita tyydyttävien tuotantovoimien kehittymisen myötä). Tällaisessa tulkinnassa välttämättömyyden valtakunta saisi määräytyneisyytensä välttämättömyyden sfääriksi pelkästään yhteiskunnallisten ominaisuuksiensa perusteella ja sen alueella tapautuvan toiminnan itsetoteutuksellisuutta mahdollisesti rajoittavat tuotantoprosessin luonteeseen ja kohteeseen liittyvät seikat tulisivat merkityksellisiksi vain suhteessa tähän yhteiskunnalliseen määräytyneisyyteen.

Vastaavalla kokonaisyhteiskunnallisella (käyttöarvo) talouden tasolla, jolla välttämättömyyden valtakunta määrittyy, ei vapauden valtakunnalle ymmärtääkseni voida antaa positiivisia määreitä. Se jää negatiivisesti määritetyksi välttämättömän työn ulkopuolelle jäävänä alueena. Tähän viittaa sekin, että kun Marx yrittää kuvata sitä positiivisesti toteamalla, että siellä tapahtuu "inhimillisten voimien kehitys, joka on itsetarkoitusta" (Marx 1976, 808), hän ei pysty antamaan tälle itsetarkoituksellisuudelle määreitä ja tulee näin vain toistaneeksi sen, ettei kyseinen alue määrity "puutteen ja ul- kopuolisen tarkoituksenmukaisuuden sanelemana työntekona".

Vapauden ja välttämättömyyden valtakuntien yhteiskunnallisen määräytyneisyyden perusteella eikä toiminnan luonteen perusteella tapahtuvaa erottelua puoltaa myös se, että Marx ei sano vapauden valtakunnan olevan kaiken aineellisen tuotannon vaan varsinaisen aineellisen tuotannon alueen tuolla puolen. Siten toiminnan ei sen alueella tarvitse (yksilötasolla) olla vailla ulkopuolista päämäärää (aristotelinen tulkinta) tai vailla esineellisyyttä (kantilainen tulkinta). Näin toiminta voi molemmissa sfääreissä periaatteessa saada millaisia määreitä tahansa (tosin sillä edellytyksellä ettă välttämättömyyden valtakunnassa tapahtuvan toiminnan luovuutta ja itsetoteutuksellisuutta aina rajoittaa sille yhteiskunnallisesti annettu päämäärä). Se, millaisia määreitä toiminta toisen tai toisen sfäärin alueella kulloinkin saa, on historiallisesti kontingentti kysymys. Tältä pohjalta voidaan kritisoida myös Schanzia - jonka erottelua vapauden ja välttämättömyyden valtakuntien välillä muutoin voidaan tulkita yhteiskunnallisen määräytyneisyyden perspektiivistä lähtien - siitä, että hän suoraan liittää Marxin vapaan ajan käsitteeseen myös ajatuksen yksilöiden aidosta itsetoteutuksesta. Edellä sanotun pohjalta tämä on virheellistä, koska vapaa aika tarjoaa vain edellytykset toiminnalle, joka voi olla joko vieraantunutta tyhjän ajan viettoa tai aitoa itsetoteutusta. Schanzin puolustukseksi voidaan tosin sanoa, että myös Marxilla itsellään esiintyy paikoin vastaava taipumus liittää itsetoteutus suoraan vapaan ajan käsitteeseen. Tämä tietysti osoittaa vain sen, että aiheen käsittely jäi Marxilta kesken, mutta ei sitä ettei vapauden ja välttämättömyyden valtakuntien erottelun rationaalinen ydin hänen tuotannossaan olisi juuri erossa yhteiskunnalli- 
sesti välttämättömän työn suorittamiseen kuluvan ajan ja vapaan ajan välillä.

\section{Kommunismin ensimmäisestä vaiheesta}

Jos työstä voitaisiin tehdä ensimmäinen elämäntarve, olisi erottelu vapauden ja välttämättömyyden valtakuntien välillä tietysti tarpeeton ( ja tällä tavalla myös toiminnan luonne on mukana valtakuntien välisessä erottelussa, mutta vain em. yhteiskunnallisen välityksen kautta). Mm. Agnes Heller (1978) onkin todennut, että Marxilla on tendenssi liittää ajatus vapauden ja välttämättömyyden valtakunnista käsitykseen, jonka mukaan työ välttämättömyyden valtakunnassa sisältää vierasmääräytyneitä elementtejä ja ehkä jopa redusoituu abstraktis-yksinkertaiseksi keskimääräistyöksi. Hyvin saman tyyppisesti mm. Schanz (1981), Marcuse (1969) ja Gorz (1982) näkevät toiminnan välttämättömyyden valtakunnassa ensisijaisesti uhrauksena, jolla vapauden valtakunnassa tapahtuvan luovan toiminnan edellytykset taataan. Ajatus työstä ensimmäisenä elämäntarpeena liittyisi tällöin toiseen yhteyteen ja kuvaisi maailmaa, joka ei olisi jakautunut vapauden ja välttämättömyyden valtakuntiin vaan olisi täydellisen vapauden toteutuma: todellinen kommunismi.

Jos nyt liitämme keskusteluun Gronowin edellä referoidun ja varsin murskaavan tuntuisen "todellisen kommunismin" kritiikin ja edelleen huomioimme sen, ettei kukaan tiettävästi ole onnistunut kehittämään edes konkreettisuutta lähentelevää utopiaa yhteiskunnasta, joka sekä säilyttäisi kapitalismin sivilisoivien vaikutusten edut että voisi tehdä työstä ensimmäisen elämäntarpeen (kuten Marx todellisesta kommunismista puhuessaan "lupasi"), on mahdollista siirtää keskustelun painopistettä. Koko keskustelu va- pauden ja välttämättömyyden valtakunnista voidaan käydä "kommunismin ensimmäisen vaiheen" tasolla. Tärkeimmät tällöin asettuvat ongelmat ovat:

(1) Kuinka paljon ja kuinka vierasmääräytynyttä työtä on tehtävä välttämättömyyden valtakunnassa tarvetyydytyksen halutun "asteen" turvaamiseksi? (Tähän liittyy myös se, että monessa suhteessa työn vierasmääräytyneisyyden aste ja työhön vaadittava aika näyttävät ainakin kapitalistisissa työprosesseissa olevan käänteisessä suhteessa toisiinsa. Ilmiö ei ehkä ole puhtaasti kapitalismispesifi.)

(2) Kuinka raja vapauden ja välttämättömyyden valtakuntien välillä vedetään eli $\mathrm{kuka} / \mathrm{mi}$ kä ja miten määrittää yhteiskunnallisesti välttämättömän työn ja tuotannon määrän ja sisällön.

Nämä ovat sekä tutkimuksen että poliittisen valinnan kysymyksiä. Esitän seuraavassa pari viitettä siihen tapaan, jolla näitä ongelmia mielestäni olisi lähestyttävä pyrittäessä rakentamaan ei-kapitalistista konkreettista utopiaa.

Jos Gorz on oikeassa väittäessään, että jo nykyisillä resursseilla olisi mahdollista supistaa yksilökohtainen työaika kehittyneissä teollisuusmaissa noin puoleen nykyisestään, mikäli työ jaettaisiin tasan ja kapitalistisesta lıäarvon anastuksesta ('voittomotiivi' Gorzilla) luovuttaisiin, ei välttämättömyyden valtakunnassa tehtävän työn suorittaminen hyvinkin heteronomisina (siis nykyisen tyyppisinä tai nykyistä heteronomisempina) työprosesseina näytä työläisten kannalta mahdottomalta vaihtoehdolta. Tämä ei tarkoita, että teknologiakritiikki ja vaihtoehtoiseen tuotantoon kohdistuvat pohdinnat ja kokeilut olisivat turhia tai merkityksettömiä. Kyse on vain siitä, että konkreettinen utopia voidaan rakentaa olemassa olevien tuotannollisten koneistojen ja teknologian vallitsevan kehityslinjan varaan. Näissäkin oloissa olisi mahdollista toteuttaa se Marxin lausuma, jonka mukaan "vapaa aika muuttaa haltijansa erilaiseksi subjektiksi ja tänä erilaisena subjektina hän osallistuu välittömään tuotantoprosessiin" (Grundrisse, 559).

Ongelma välttämättömyyden valtakunnan alueen määrittämisestä on vaikeampi, eikä esim. Gorz pysty sanomaan siihen mitään mielekästä. Kapitalismissa yhteiskunnallisesti välttämätön työ määrittyy markkinoiden kautta, mutta kuinka se voitaisiin määrittää yhteiskunnassa, joka on poistanut markkinat tai asettanut ne alisteiseen asemaan käyttöarvo-orientuneeseen suunnitteluun nähden. Ongelma on tietysti vaikea vain sillä edellytyksellä, että ei tahdota hyväksyä valtiollisen suunnittelueliitin "diktatuuria tarpeiden yli".Agnes Heller (1982) on pyrkinyt ratkomaan tätä ongelmaa puhumalla "demokraattisesta tarvekeskustelusta". Sen perusajatuksena on, ettei voida varsinaisesti puhua "tosista" ja "vääristä" tarpeista, koska ei ole olemassa mitään yksinomaista oikeaa tarverakennetta, johon ihmisten tarveartikulaatioita voitaisiin verrata. Siksi kaikki tarpeet on tunnustettava todellisiksi. Tämä ei kuitenkaan tarkoita sitä, että kaikki tarpeet tulisi tyydyttää. Tyydytettävistä tarpeista on ensinnäkin rajattava pois toisia ihmisiä vahingoittava tarpeentyydytys (tämän Heller esittää eräänlaisena kategorisen imperatiivin muunnelmana: "toimi aina niin, että et käytä ihmisyyttä toisessa ihmisessä pelkkänä välineenä vaan päämääränä sinänsä"). Tämän periaatteen tulkinnoista voidaan Hellerin mukaan kussakin yhteiskunnallisessa tilanteessa aina riittävän tarkasti sopia. Toiseksi asettavat yhteiskunnalliset resurssit aina esteitä kaikkien tarpeiden tyydy- 
tykselle. Siksi on voitava laatia preferenssijärjestys, jossa eri tarpeet toteutetaan (tarpeiden preferenssijärjestyksen laadinta sisältää Hellerillä useita nyansseja, joihin ei tässä ole tarpeen puuttua). Tämän preferenssijärjestyksen laatimisen yhteyteen kuuluisi tietysti myös edellä puheena ollut välttämättömyyden valtakunnan alueesta päättäminen. Preferenssijärjestys on voitava laatia demokraattisessa tarvekeskustelussa, jossa kaikkien tarpeet tunnustetaan ja niiden annetaan päästä esiin. Kyse on siis habermasilaisesta herruudesta vapaasta kommunikaatiosta.

Hyvin yleisesti ottaen voitaisiin siis välttämättömyyden valtakuntaa tarkastella "gorzilaisittain" ja vapauden ja välttämättömyyden valtakuntien suhdetta "helleriläisittäin". Käsittelemättä jäisi siis enää vapauden valtakunta - ja siinä juuri on koko ajatus! Sen pitäisikin jäädä käsittelemättä. Jos nimittäin luotamme siihen Agnes Hellerin (1983) ajatukseen, että yhden "hyvän elämän" määrittävän rakenteen sijasta modernille maailmalle on luonteenomaista, että "hyvä elämä" on pirstoutunut ja pirstoutumassa erilaisiin inhimillisiin yhteisöihin, joilla on erilaiset elämäntyylit ja toisistaan poikkeavat normatiivis-moraaliset "hyvän elämän" määritelmät, ei ole mitään syytä rakentaa yhtä vapauden valtakuntaa. Riittää kun näiden erilaisten yhteisöjen ja alakulttuurien välillä toimii demokraattinen tarvekeskustelu ja ne ovat yhteydessä toisiinsa osallistumalla tarvekeskustelussa sovituin panoksin välttämättömyyden valtakunnan toimintaan. Vain näin voidaan säilyttää vapauden valtakunnan maksimaalinen vapaus.

Tietysti on selvää, että demokraattisen tarvekeskustelun perustalla on tiettyjä normatiivisia kannanottoja, jotka asettavat alakulttuurit eriarvoiseen asemaan. Vaikuttaa kuitenkin siltä, että se on vähiten yksilöiden ja alakult- tuurien identiteettiä runteleva tapa säilyttää yhteiskunnan kiinteys ja estää anarkian synty. Mikään ei tietystikään estä kommunismin ensimmäisen vaiheen ihmisiä kehittämästä sen tilalle jotain parempaa mallia.

\section{Risto Heiskala}

\section{Kirjallisuutta:}

Castoriadis, Cornelius (1978): From Marx to Aristotle, from Aristotle to Us. Social Research vol 45, 1978:4.

Gorz, André (1982): Farväl till proletariatet, bortom socialismen. Stockholm.

Heller, Agnes (1978): The Theory of Need in Marx. London and Worcester.

Heller, Agnes (1982): Missä mielessä voidaan puhua "tosista" ja "vääristä" tarpeista? Uudistuva Ihmiskunta 1982:4.

Heller, Agnes (1983): The Dissatisfied Society. Praxis International vol 2, 1983:4.
Lohmann, Georg (1983): "Wealth" as an Aspect of the Critique of Capital. Paper presented at the International Conference "Rethinking Marx - 100 years after his Death", Berlin 17. - 20.2.1983.

Marcuse, Herbert (1969): Yksiulotteinen ihminen. Teollisen yhteiskunnan tarkastelua. Tapiola.

Marx, Karl (1979): Gothan ohjelman arvostelua. Teoksessa Marx-Engels: Valitut teokset, 6 osaa. Moskova.

Marx, Karl (1976): Pääoma. Kansantaloustieteen arvostelua. 3 osa. Moskova.

Oetzel, Klaus-Dieter (1978): Wertabstraktion und Erfahrung. Über das Problem einer historisch-materialistischen Erkenntniskritik. Frankfurt/Main.

Schanz, Hans Jørgen (1981): Traek af behovsproblematikkens idehistorie med saerligt henblik på Marx og Engels. Århus.

Theunissen, Michael (1978): Sein und Schein. Die kritische Funktion der Hegelschen Logik. Frankfurt am Main.

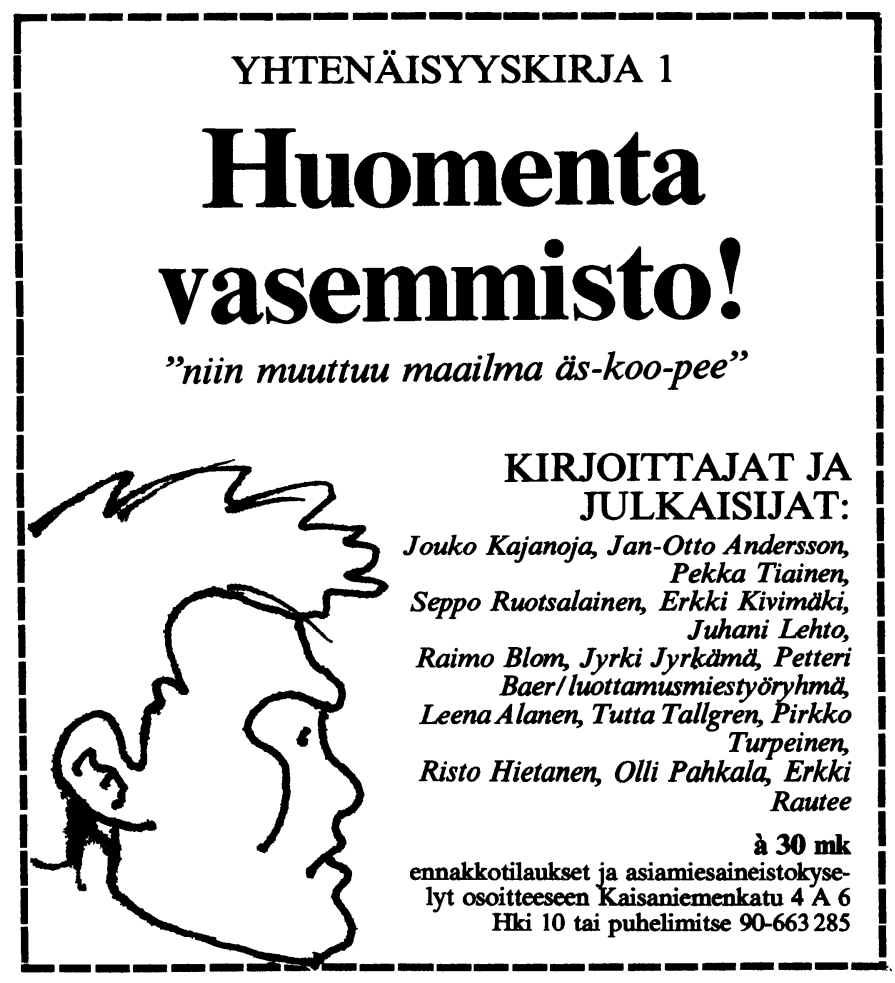

